\title{
Distribution, habitat profile and genetic variability of Namibian succulent Lithops ruschiorum
}

\begin{tabular}{|c|c|}
\hline \multicolumn{2}{|c|}{ 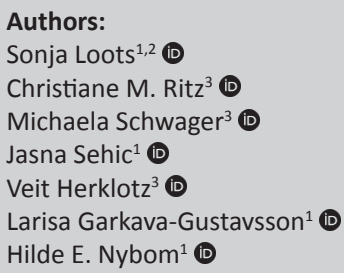 } \\
\hline \multicolumn{2}{|c|}{$\begin{array}{l}\text { Affiliations: } \\
{ }^{1} \text { Department of Plant } \\
\text { Breeding, Swedish University } \\
\text { of Agricultural Sciences, } \\
\text { Alnarp, Sweden }\end{array}$} \\
\hline \multicolumn{2}{|c|}{$\begin{array}{l}{ }^{2} \text { National Botanical Research } \\
\text { Institute, Ministry of } \\
\text { Agriculture, Water } \\
\text { and Forestry Namibia, } \\
\text { Windhoek, Namibia }\end{array}$} \\
\hline \multicolumn{2}{|c|}{$\begin{array}{l}{ }^{3} \text { Senckenberg Museum } \\
\text { of Natural History Görlitz, } \\
\text { Görlitz, Germany }\end{array}$} \\
\hline \multicolumn{2}{|c|}{$\begin{array}{l}\text { Corresponding author: } \\
\text { Sonja Loots, } \\
\text { sonja.loots.solo@gmail.com }\end{array}$} \\
\hline \multicolumn{2}{|c|}{$\begin{array}{l}\text { Received: } 06 \text { Aug. } 2018 \\
\text { Accepted: } 04 \text { Apr. } 2019 \\
\text { Published: } 01 \text { Aug. } 2019\end{array}$} \\
\hline \multicolumn{2}{|c|}{$\begin{array}{l}\text { How to cite this article: } \\
\text { Loots, S, Ritz, C.M., } \\
\text { Schwager, M., Sehic, J., } \\
\text { Herklotz, V., Garkava- } \\
\text { Gustavsson, L. et al., 2019, } \\
\text { 'Distribution, habitat profile } \\
\text { and genetic variability of } \\
\text { Namibian succulent Lithops } \\
\text { ruschiorum', Bothalia 49(1), } \\
\text { a2408. https://doi.org/ } \\
\text { 10.4102/abc.v49i1.2408 }\end{array}$} \\
\hline \multicolumn{2}{|c|}{$\begin{array}{l}\text { Copyright: } \\
\text { (C) 2019. The Authors } \\
\text { Licensee: AOSIS. This } \\
\text { is licensed under the } \\
\text { Creative Commons } \\
\text { Attribution License. }\end{array}$} \\
\hline \multicolumn{2}{|l|}{ Read online: } \\
\hline 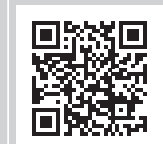 & $\begin{array}{l}\text { Scan this QR } \\
\text { code with your } \\
\text { smart phone or } \\
\text { mobile device } \\
\text { to read online. }\end{array}$ \\
\hline
\end{tabular}

Background: The species-rich flora of southern Africa comprises a high number of endemics, including succulents such as the flowering stones in the genus Lithops, but conservation status for these species is not well underpinned because detailed field data and assessments of genetic diversity are lacking.

Objectives: We wanted to assess plant abundance and identify factors that may affect survival in Lithops ruschiorum through carefully conducted field surveys, and to determine amount and partitioning of genetic variation by amplified fragment length polymorphism (AFLP) analysis.

Method: Field surveys were carried out in nine populations in Namibia. The most meticulously studied population was divided into 51 sites, while another 43 sites were recognised in the remaining eight populations. At each site, occupied area and number of plants were recorded as well as altitude, aspect, slope, soil texture and substrate. Amplified fragment length polymorphism markers were employed to study 52 individuals from seven populations.

Results: In total, 8465 individuals were recorded. Plant density and/or plant number was associated with aspect, slope, soil texture, substrate and geographic distance from the coast. Analysis of molecular variation showed that $95 \%$ of the variability occurs within populations. Genetic and geographic distances among populations were correlated suggesting an isolationby-distance pattern.

Conclusion: Results are concordant with a strong impact of fog-based precipitation on plant density in the coastal populations, whereas rain probably is more important at one population which is situated further inland. Within-population genetic variation was medium high as usually reported for perennial, outcrossing species, but the low population differentiation implies considerable gene flow and/or population fragmentation.

Keywords: abundance; AFLP; desert biome; molecular marker; plant conservation; plant inventory; population genetics.

\section{Introduction}

Southern Africa harbours many endemic leaf succulents because of the unique environmental conditions (Young \& Desmet 2016), but few of these taxa have been thoroughly studied in spite of imminent threats due to climate change and human activities such as illegal collecting of seeds and live plants, and habitat destruction resulting from prospecting, mining, off-road driving and, in recent years, the production of motion pictures in different parts of the Namib desert (Jainta 2017; Loots 2005, 2011). Decisions about conservation status and suitable protection measures are therefore not well underpinned. Methods for assessing plant abundance in sometimes cryptic species are needed, and factors that affect plant recruitment and survival should be determined. In addition, information on amount and partitioning of genetic variation is needed for determination of proper protection measures.

One of the insufficiently studied succulent genera is Lithops N.E.Br., which comprises 37 species (Cole 2006; Cole \& Cole 2005) that are often referred to as stone plants or flowering stones because of their ability to blend in with their substrates on gravelly plains, rocky outcrops and slopes, which make them very difficult to detect and study. Individual plants can reach an age of at least 50 years (Schwantes 1957). Recruitment of new plants is erratic, with seed dispersal, germination and seedling establishment depending on unpredictable rainfall events. Many narrowly distributed plant species, such as Lithops, have a strong dependency on specific habitats, which, in combination with restricted gene flow, can lead to population fragmentation and subsequent extinction (IUCN 2001). Apart from a previous study on 
methods to determine plant density and habitat preferences in L. pseudotruncatella (Loots \& Nybom 2017), in-depth field surveys in the genus are lacking. Studies on population genetics and intraspecific variation have also not been reported for the genus.

For this study, we focus on L. ruschiorum (Dinter \& Schwantes) N.E.Br., which is endemic to Namibia and easily distinguishable from other Lithops species by its highly cordate profile, leaves that are often elevated above the soil surface and the very smooth, pale white to greyish or buff-coloured leaf face with few markings (Figure 1). Two varieties are acknowledged based mainly on leaf colouring and markings: the southerly distributed var. ruschiorum and the northerly distributed var. lineata (G.C.Nel) D.T.Cole. The yellow, 12-30-mm-wide flowers (Cole \& Cole 2001) usually start to open in January, but flowering can be triggered by episodic rainfall events any time of the year. The broadly elliptic seed capsules are 5-6 locular and contain seeds without any features for dissemination enhancement (Cole \& Cole 2005). Lithops ruschiorum has a shallow root system, drawing water from the uppermost $5 \mathrm{~cm}$ of the soil layer and must compete with other species in the same layer. Other challenges include herbivorous insects and larger herbivores such as domestic and wild ungulates. The current conservation status is Least Concern (IUCN 2001; Klaassen \& Kwembeya 2013).

Populations of L. ruschiorum can be found in many, apparently different, microhabitats. Defining population boundaries is problematic because potentially suitable habitat can continue for several square kilometres, interrupted only by minor geographic boundaries that separate groups of plants, such as dry stream beds or unsuitable rock substrates. Within such an occupied area, aggregations of plants frequently occur at varying distances from one another. It is not clear whether these colonies are remnants of a once larger population that has become fragmented. The occurrence of separate small plant colonies can also stem from a close dependency on particular microhabitat features that are not immediately evident from the habitat at large, as previously demonstrated in L. pseudotrunctella which had a highly clumped distribution with more than $80 \%$ of the plants occurring on just $20 \%$ of an apparently suitable habitat (Loots \& Nybom 2017). Plant density was positively correlated with a high percentage cover of gravel and pebbles.

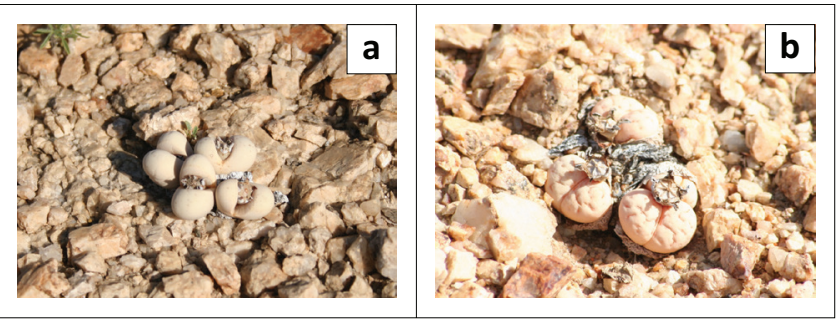

Source: Photo courtesy of Sonja Loots

FIGURE 1: Plants of Lithops ruschiorum showing (a) a healthy plant in profile with the fissure clearly visible and developing capsules in a feldspar habitat and (b) a healthy plant with old leaves in the centre and three ripe, 6-7-locular seed capsules in a mixed gravel habitat.
Genetic variability and processes, such as isolation-bydistance and genetic drift, can be studied by deoxyribonucleic acid (DNA)-based markers, and appear to be closely associated with life form, breeding system, mode of seed dispersal and successional status (Nybom 2004). Amplified fragment length polymorphism (AFLP) markers were used to study interspecific variation among Lithops taxa, and to define nine clades within the genus (Kellner et al. 2011). Intraspecific variation has, however, as yet not been studied with molecular markers in Lithops.

The current study was undertaken to estimate plant abundance in L. ruschiorum throughout its known distribution range in Namibia, including assessments of spatial population structure and the impact of habitat selection and climatic conditions. In addition, AFLP markers were applied to assess molecular variation between and within populations, and thus identify a possible isolation-by-distance pattern.

\section{Material and methods Study area and habitat parameters}

Lithops ruschiorum grows in the central and northern desert biome of Namibia (Irish 1994), and has a distribution area that stretches more than 600 kilomtres $(\mathrm{km})$ along the coast and approximately $75 \mathrm{~km}$ inland (Cole \& Cole 2005). The central Namib desert is characterised by temperatures of -0.7 to 42 degrees Celsius $\left({ }^{\circ} \mathrm{C}\right)$ close to the coast, while areas further inland vary between -1.2 and $43^{\circ} \mathrm{C}$. Annual rainfall is very sparse and unpredictable, but ranged from 17 millimetres ( $\mathrm{mm}$ ) closer to the coast to $87 \mathrm{~mm}$ further inland. Most of the precipitation is instead received as advective and high fog, caused by moist air flowing over the cold Benguela current along the Namibian coastline, reaching over $100 \mathrm{~km}$ inland and ranged from $183 \mathrm{~mm}$ near the coast to $3 \mathrm{~mm}$ further inland per year (Lancaster, Lancaster \& Seely 1984). Average annual rainfall in the northern Namib ranges from 11 to $42 \mathrm{~mm}$ (Irish 1994). Other climate data for the northern Namib desert are still lacking. The terrain consists of vast gravel plains interrupted by inselbergs, low-lying, undulating hills, ridges and ephemeral river courses with riparian vegetation. Soils are usually sandy, but some silt, loam and clay occur. Most of the localities for L. ruschiorum are found within the Skeleton Coast National Park and Dorob National Park.

Lithops ruschiorum has the second largest distribution of all Namibian Lithops species, but still only 21 populations have been recorded (Cole \& Cole 2005; Loots collection data 2006-2014; WIND 2006). Information on the precise location of these populations was obtained from the National Herbarium (WIND) specimen database, literature (Cole 1988a, 1988b) and local experts. Field trips were undertaken from October 2006 to September 2008 to locate the populations, and to survey nine populations from southeast of Rössing Mountain and Rössing Uranium Limited (RUL) license area in the central Namib desert, to Khumib River in the northern Namib (Figure 2). In 2011, 


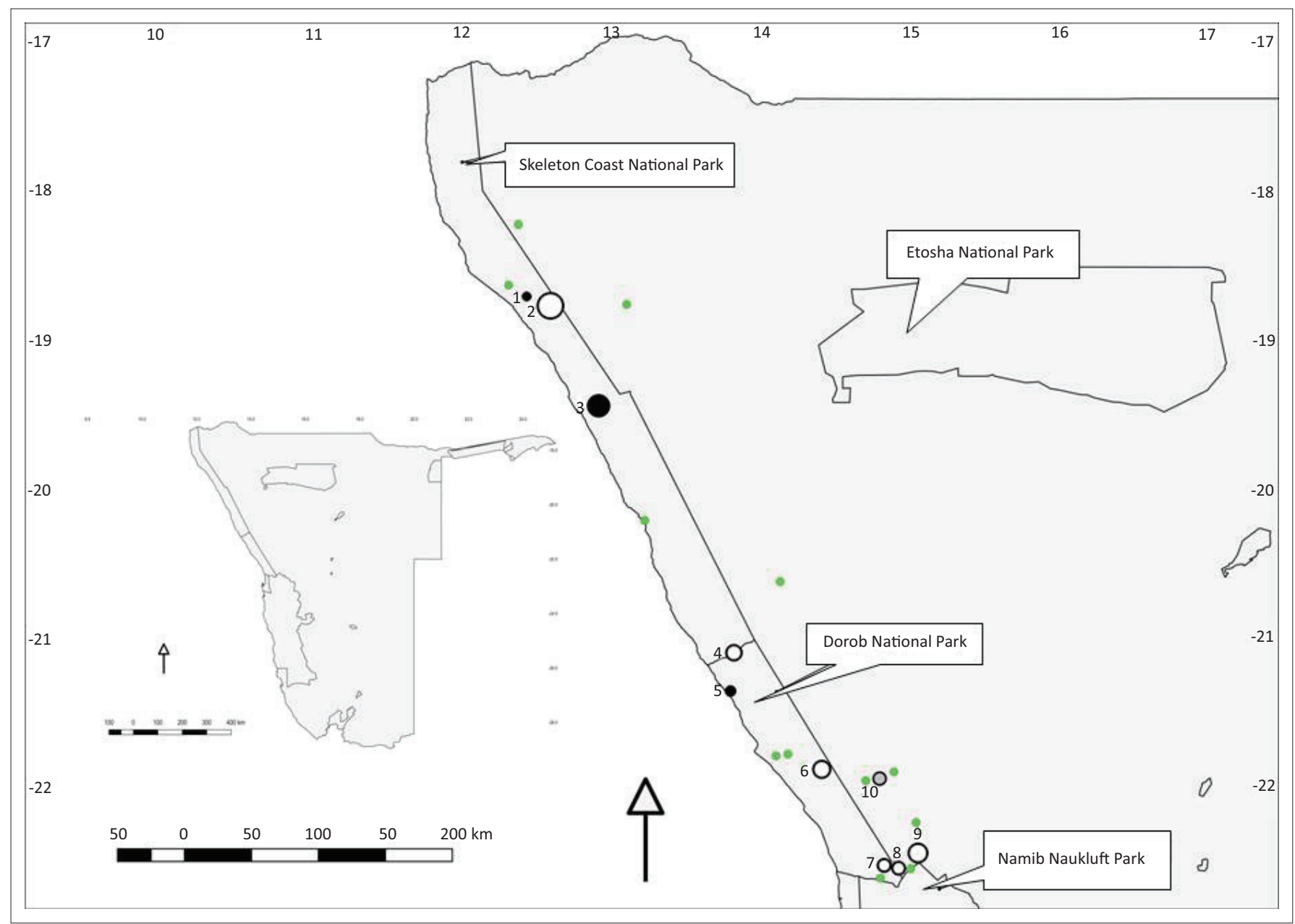

$\mathrm{km}$, kilometres.

FIGURE 2: Distribution of surveyed Lithops ruschiorum populations. 1. View Point, 2. Khumib River, 3. Hoanib River, 4. Ugab River, 5. Ugab Salt Works, 6. Henties Bay-Uis Road, 7. Rössing Mountain, 8. Feldspar Ridge, 9. Rössing Uranium Limited (RUL) license area, 10. Henties Bay-Usakos Road. Circle size is roughly proportional to number of plants observed in each population. Populations used for collecting demographic data: black circle, populations used for collecting seed: grey circle, populations used for both purposes: unfilled circle. In addition, the total distributional area determined from all 21 recorded populations is shown (small green dots).

seeds were collected from the surveyed populations and the additional Henties Bay-Usakos Road population.

Boundaries are difficult to define for large populations that consist of many small and widely dispersed groups of plants. In this study, a site is defined as a group of plants that grow together on the same topographic feature such as a ridge, outcrop, slope or a gravel plain, and with no plants separated by unsuitable habitat. By contrast, sites within a population can be separated by unsuitable habitat although crosspollination between sites should still be possible. A population is defined as a group of sites occurring at the same geographic location. Populations are separated by significant distances (minimum $10 \mathrm{~km}$ ), unsuitable habitat and/or geographic barriers, making inter-populational cross-pollination unlikely. Only one site constitutes the entire population at View Point in the Skeleton Coast Park. For each population, number of sites, plants and occupied area are shown in Table 1.

One very large population, RUL, received special attention because of its size and previous plant and habitat analyses. Burke (2005) divided this population into 20 biotopes based on the number of endemic and Red
TABLE 1: Investigated populations with number of sites, number of plants and occupied area.

\begin{tabular}{lccr}
\hline Population & Sites & Plants & Area $\left(\mathbf{m}^{\mathbf{2}}\right)$ \\
\hline Feldspar Ridge & 2 & 307 & 19362 \\
Henties Bay-Uis Road & 11 & 1158 & 66716 \\
Hoanib River & 4 & 1380 & 23608 \\
Khumib River & 6 & 2213 & 16004 \\
Rössing Mountain & 5 & 418 & $>12033$ \\
Rössing Uranium Limited (RUL) & 51 & 2008 & $>51562$ \\
Ugab River & 12 & 741 & 15766 \\
Ugab Salt Works & 2 & 148 & 8979 \\
View Point & 1 & 92 & 500 \\
\hline Total & $\mathbf{9 4}$ & $\mathbf{8 4 6 5}$ & $>\mathbf{2 1 4 5 3 0}$ \\
\hline
\end{tabular}

List species in each biotope. Twelve of these contained L. ruschiorum and/or Adenia pechuelii (Engl.) Harms, another endemic succulent plant surveyed simultaneously. In the present study, a total of 68 sampling points, $1 \mathrm{~km}$ apart in grid square format, were drawn on a map to cover the 12 biotopes. Seven additional sampling points were placed in parts not covered by the grid, but known to contain dense clusters of Lithops. Each sampling point was marked with a set of Global Positioning System (GPS) coordinates (in WGS84 format) saved as waypoints in a GPS to enable 
subsequent retrievals. Each individual Lithops plant observed within $500 \mathrm{~m}$ of a sampling point was temporarily marked with a coloured marker (Mannheimer \& Loots 2012). If more than one site could be identified after marking all the plants found within a $500 \mathrm{~m}$ radius, a set of GPS coordinates was recorded in the centre of each site. In addition, altitude, aspect (the compass direction that a slope faces), slope (steepness of a sloping surface), soil texture and rock substrate were recorded for each site (Appendix 1, Table 1a-A1). Number of mature plants (plants capable of reproduction), juveniles (plants that are flat on top and with as yet unseparated facial lobes) and damaged plants (with extensive predatory damage) was then determined for each site. The occupied area was measured for each site using the track log function of the GPS, recording one set of coordinates every second while walking along the outer boundary of detected plants. This parameter was then used to calculate the density of each site (number of plants $/ \mathrm{m}^{2}$ ). A total of 22 soil samples were taken in different sites, and $\mathrm{pH}$ was determined for each sample using a Hanna microprocessor $\mathrm{pH}$ metre.

In each of the other eight successfully located populations, all Lithops plants were temporarily marked using coloured markers. When more than one site could be identified, the boundary for each site was demarcated with the GPS track $\log$ function. Data for habitat parameters were recorded as for RUL (Appendix 1, Table 1b-A1). Distance from each site to the sea coast was determined using the ruler function in Google Earth. One soil sample was taken from each population for $\mathrm{pH}$ determination.

Only one population (Khumib River) contained plants that were identified as var. lineata, but individuals of var. ruschiorum were growing in the same sites. No distinction was therefore made between sites or populations on the basis of intraspecific taxonomy. In populations with a sufficient number of plants, a single L. ruschiorum specimen was collected to ensure adequate representation in the National Herbarium (WIND) and for positive identification.

\section{Molecular analyses}

Seed capsules were collected from seven populations (Figure 2). Where possible, at least ten plants were sampled across the known geographical range of each population. A photograph was taken of each sampled plant for reference purposes. In populations where seed was scarce, but the plants produced many heads, a single fresh half leaf was collected from ten multi-headed plants and stored directly in silica gel for DNA extraction. Up to 50 seeds per sampled plant were sown in pots in a greenhouse in Alnarp in Sweden, with $14 \mathrm{~h}$ of light per day, and temperatures of $22-25^{\circ} \mathrm{C}$. Between 8 and 10 seedlings per population, each from a different mother plant, were sampled for DNA extraction after one year of growth. Deoxyribonucleic acid extraction was performed using the DNeasy Qiagen DNA Plant Mini Kit, according to manufacturer's instructions, with two modifications: all centrifugations were run at 14000 revolutions per minute (rpm), and in the last step, the DNA was eluted in only $2 \times 50$ microlitres $(\mu \mathrm{L})$ to prevent excessive dilution of samples with low DNA concentration.

Genetic variation was investigated using standard AFLP procedure (Vos et al. 1995) except that restriction and ligation were performed simultaneously at $37^{\circ} \mathrm{C}$ overnight. Based on an extensive primer screening in a previous analysis of the genus Lithops (Kellner et al. 2011), three selective primer pair combinations were chosen: E32/M48 (AAC/CAC), E35/M51 (ACA/CCA) and E46/M51 (ATT/CCA). In addition, the primer combination E33/M47 (AAG/CAA) was also used. To avoid direct labelling of specific primers, we used the 'poor man's approach' according to Schuelke (2000). Polymerase chain reactions (PCR) were performed using an Eppendorf Mastercycler gradient S (Eppendorf AG, Hamburg, Germany). Automated detection of AFLP fragments was carried out by the Senckenberg Biodiversitäts- und Klimaforschungszentrum (Frankfurt am Main, Germany), using an ABI 3730 sequencing machine and the size standard LIZ-600 (ABI Life Technologies, Darmstadt, Germany). To ensure unambiguous scoring of AFLP fragments, ten positive controls were repeated in each run; thus, each of the positive controls was run three to five times in total. Amplified fragment length polymorphism profiles were scored as presence (1) and absence (0) of fragments ranging from 80 to 300 base pairs, using the software Genographer 2.1.4 (Banks \& Benham 2008). Bands that were detected in $<75 \%$ of repetitions of the positive controls were deleted.

\section{Statistical analyses}

The numerical plant and habitat parameters (altitude, slope, distance from coast, occupied area, plant number and plant density) were tested for normality using the Anderson Darling test and transformed into natural logarithms as needed. Statistical analyses of plant and habitat parameters were carried out on two separate data sets: (1) sites in the RUL population and (2) sites in the other eight populations. Firstly, the relationships between occupied area, plant number and plant density were estimated by Spearman rank correlation analyses. Subsequently, associations between plant parameters and habitat parameters were estimated using univariate (including all data, i.e. 51 and 43 sites, respectively) and multivariate methods (including only 29 and 26 sites, respectively, because of list-wise deletion of missing values). Spearman rank correlation analyses were performed to study associations between the numerical habitat parameters (altitude, slope and coastal distance) and plant number and plant density. Several one-way analyses of variance (ANOVA) were performed to study the possible impact of category habitat parameters (aspect, substrate and soil texture) on plant number and plant density, followed by Tukey pairwise comparisons. Because of the unbalanced number of sites for especially aspect, some alternatives were merged into wider groups (e.g. $\mathrm{NE}+\mathrm{N}+\mathrm{NW}$ ). A general linear mixed model (GLM) was used to analyse the effects of all parameters (altitude, slope, coastal distance, aspect, substrate and soil texture) simultaneously and their interactions as 
fixed effects, and sites per populations as random effects, on plant density and total plant number. The analyses were performed under the $\mathrm{R}$ environment ( $\mathrm{R}$ Core Team 2018) using the lmer function implemented in the lme4 package (Bates et al. 2015) with $p$ values obtained from lemeTest package (Kuznetsova, Brockhoff \& Christensen 2016). Best fitting models were discovered by model simplification procedures starting with a full model containing all factors and their interactions, and a subsequent stepwise reduction of the full model. An ANOVA comparing all models was used to select the best fitting one.

Principal component analyses (PCAs) were performed to explore the relationships between the habitat parameters, using indicator (dummy) variables for aspect, substrate and soil texture. In addition, plant number and occupied area were entered into the analysis to highlight the co-occurrences (but not the causality) between these parameters and the habitat parameters.

The AFLP data were used to estimate genetic variance within and among populations by an analysis of molecular variance (AMOVA) using GenAlEx v.6.5 (Peakall \& Smouse 2012). Genetic diversity within populations was estimated as percentage of polymorphic loci and as expected heterozygosity $\mathrm{H}_{\mathrm{E}}$, which is equivalent to Nei's unbiased gene diversity (Nei 1978) when calculations are based on polymorphic, biallelic loci and when number of samples are equal among populations. Genetic structuring within and among populations was evaluated with principal coordinate analysis (PCoA) with Sørensen distances using PC-ORD v.6.07. Finally, an association between genetic and geographic distances among samples was investigated with a Mantel test, computed in PC-ORD.

\section{Ethical considerations}

This article followed all ethical standards for research without direct contact with human or animal subjects.

\section{Results \\ Populations and plant counts}

During the field work in 2006-2008, only nine L. ruschiorum populations were located out of the 21 previously recorded (Figure 2). These populations were found on gravel plains, rocky ridges and outcrops, gentle to steep slopes and hill tops, and occasionally on mountain slopes. The plants were mostly growing in very gravelly soil, but occasionally in rock crevices with almost no soil, and usually in fully sun-exposed positions but sometimes in half shade.

A total of 8465 L. ruschiorum plants were recorded at the 94 sites identified in the nine populations (Table 1). The Skeleton Coast Park with populations View Point, Khumib River, Hoanib River and Ugab River contained $51 \%$ of the total number of recorded plants. The largest population was Khumib River in the northern part of this park, with over 2200 plants, and the second largest was RUL in the southern part of the distribution area, with just over 2000 plants. Because of the considerable challenges in spotting Lithops plants in their natural habitat, plant numbers reported here are certainly too low, but relative differences between populations and sites should still be accurate.

Percentage of mature plants out of the total number was $90.3 \%$, while $8.6 \%$ were damaged and $1.1 \%$ were juveniles (Appendix 1, Table 1a-A1 and 1b-A1). Juveniles are exceptionally hard to spot and many are likely to have been overlooked. The Khumib River population had the highest percentage of juvenile plants (4.8\%), while RUL had only $0.6 \%$ and View Point and Ugab Salt Works none at all. The highest percentage of damaged plants was encountered at View Point (55.4\%) followed by RUL (17.3\%) and Hoanib River (7.6\%). Plant number differed considerably between sites in the same population; for example, the 12 sites at the Ugab River ranged from just 2 to 161 plants, the eight sites at Henties Bay-Uis Road from 5 to 621 plants and the six sites at Khumib River from 49 to 692 plants. Similarly, the occupied areas differed: the four sites in Hoanib River ranged from 751 to $12397 \mathrm{~m}^{2}$, the five Rössing Mountain sites ranged from below $5000 \mathrm{~m}^{2}$ to almost $10000 \mathrm{~m}^{2}$ and the eight Henties Bay-Uis Road sites from just $200 \mathrm{~m}^{2}$ to above $20000 \mathrm{~m}^{2}$.

\section{Plant number, occupied area and plant density}

As Lithops have a very patchy distribution also on apparently suitable habitats, and as there can be significant stretches of unsuitable habitat between occupied areas within a population, all parameters related to number and density of plants were based on the sites instead of entire populations. Information about plant number and occupied area for each site is presented in Appendix 1, Tables 1a-A1 and 1b-A1.

The survey of the RUL population initially made use of 75 sampling points. While no Lithops plants could be observed in the neighbourhood of 42 of these points, the remaining 33 sampling points contained plants and could be divided into one to four sites, yielding a total of 51 sites for RUL. Occupied area ranged among the different sites from 10 to $12000 \mathrm{~m}^{2}$, with a mean of $1101 \mathrm{~m}^{2}$ (not measured for less than three plants), while plant number per site ranged from 1 to 440 with a mean of 39.4. Plant density was calculated as plant number divided by occupied area, and ranged from 0.003 to 0.797 with a mean of 0.014 plants per $\mathrm{m}^{2}$.

In the other eight populations, Lithops plants occurred in 1-12 sites per population, and a total of 43 sites were analysed. Occupied area for these sites varied from 200 to $22684 \mathrm{~m}^{2}$ with an average of $3885 \mathrm{~m}^{2}$, and plant number from 3 to 692 with a mean of 150.2. Plant density varied from 0.002 to 0.265 with a mean of 0.064 plants per $\mathrm{m}^{2}$.

The boundaries of a site (i.e. occupied area) were determined by the number of plants as well as the distances between these plants. As expected, positive correlations were obtained between occupied area and number of plants, both in RUL 
and in the other eight populations (Table 2). Occupied area and plant density were instead negatively correlated in both these data sets with the closest association found in RUL.

TABLE 2: Spearman rank correlation values for associations among occupied area, plant number and plant density, and two numerical habitat parameters (altitude and slope) at 51 sites in the Rössing Uranium Limited population, and at 43 sites in the other eight populations.

\begin{tabular}{lllcc}
\hline Parameter 1 & Parameter $\mathbf{2}$ & $\boldsymbol{r}$ & $\boldsymbol{N}$ & $\boldsymbol{p}$ \\
\hline RUL & & & & \\
Plant number & Occupied area & 0.585 & 43 & $<0.001^{* * *}$ \\
Plant number & Plant density & -0.137 & 43 & 0.369 \\
Occupied area & Plant density & -0.732 & 43 & $<0.001^{* * *}$ \\
Plant number & Altitude & 0.084 & 51 & 0.593 \\
Plant number & Slope & 0.127 & 42 & 0.454 \\
Plant density & Altitude & -0.223 & 43 & 0.150 \\
Plant density & Slope & 0.411 & 37 & $0.012^{*}$ \\
Other eight population & S & & & \\
Plant number & Occupied area & 0.676 & 41 & $<0.001^{* * *}$ \\
Plant number & Plant density & 0.418 & 41 & $0.006^{* *}$ \\
Occupied area & Plant density & -0.363 & 41 & $0.020^{*}$ \\
Plant number & Altitude & 0.195 & 40 & 0.222 \\
Plant number & Slope & 0.445 & 37 & $0.006^{* *}$ \\
Plant number & Coastal distance & -0.157 & 43 & 0.314 \\
Plant density & Altitude & 0.098 & 39 & 0.546 \\
Plant density & Slope & 0.504 & 36 & $0.002^{* *}$ \\
Plant density & Coastal distance & -0.308 & 41 & $0.047^{*}$ \\
\hline
\end{tabular}

RUL, Rössing Uranium Limited.

$*, 0.05>p>0.01 ; * *, 0.01>p>0.001 ; * * *, p<0.001$.
Number of plants and density were positively correlated in the data set with eight populations, whereas no association was found between these parameters in RUL. Both data sets have a high percentage of sites with large occupied areas that have low densities (39\% for RUL; 50\% for the other eight populations), but RUL has the highest percentage of small sites with high densities (33\% for RUL; $10 \%$ for the other eight populations), while the other eight populations have the highest percentage of sites with large occupied areas that have high densities (2\% for RUL; $19 \%$ for the other eight populations). When plants were divided into mature, damaged and juvenile, number of mature plants had the strongest correlation with occupied area, while number of juvenile plants had the weakest correlation (data not shown).

\section{Impact of habitat characteristics}

Information about habitat variables for each site is presented in Appendix 1, Tables 1a-A1 and 1b-A1. Each site was represented by the predominant aspect or substrate when several alternatives had been scored. In some cases, it was not possible to determine predominant aspect or substrate because these varied too much within site. Principal component analyses were performed on all the habitat variables together with occupied area and number of

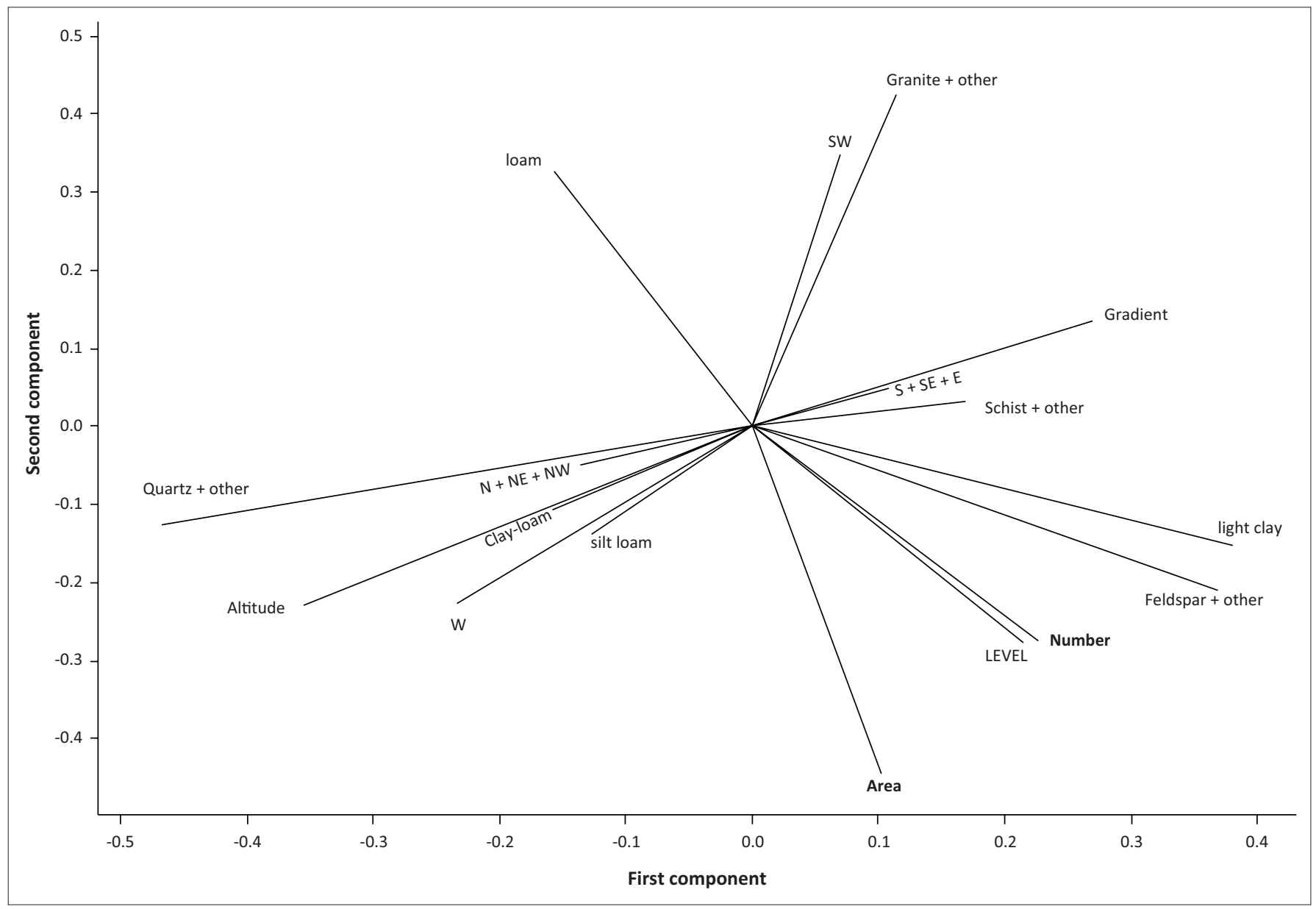

FIGURE 3: Principal component analysis showing the relationship between number of plants (Number), occupied area (Area) and habitat parameters: altitude, aspect $(\mathrm{N}+\mathrm{NE}+\mathrm{NW}, \mathrm{SW}, \mathrm{S}+\mathrm{SE}+\mathrm{E}, \mathrm{LEVEL})$, gradient (degree of slope), soil texture (loam, light clay, silt loam, clay loam) and substrate (Quartz + other, Granite + other, Schist + other, Feldspar + other) in the 51 sites at Rössing Uranium Limited. 


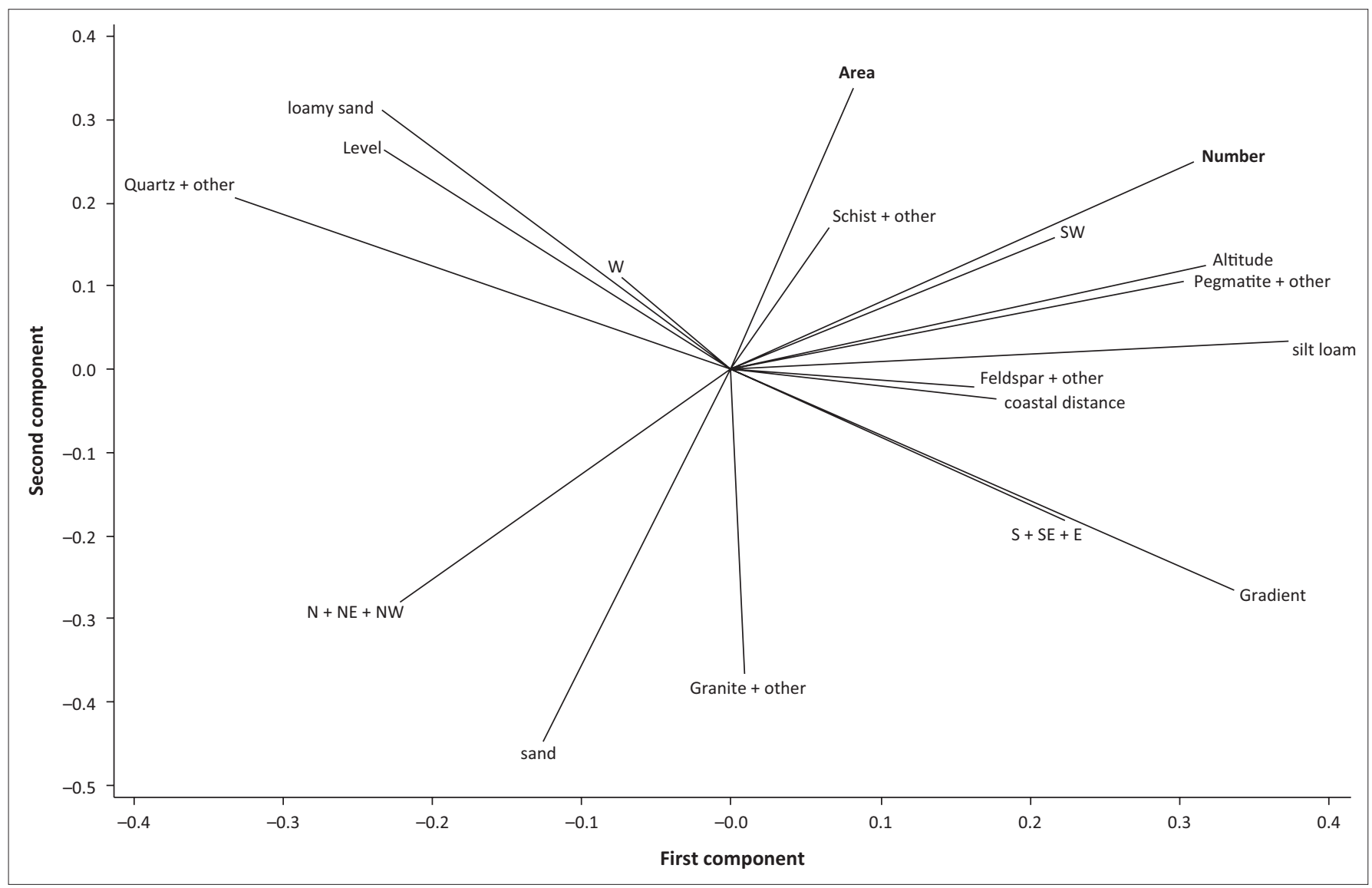

FIGURE 4: Principal component analysis showing the relationship between number of plants (Number), occupied area (Area) and habitat parameters: altitude, aspect (LEVEL, W, SW, S+SE+E, N+NE+NW), coastal distance, gradient (degree of slope), soil texture (loamy sand, silt loam, sand) and substrate (Quartz + other, Schist + other, Pegmatite + other, Feldspar + other, Granite + other) in the 43 sites of the other eight populations.

plants for RUL (Figure 3) and the eight populations (Figure 4). These descriptive analyses provide an overview of the observed associations between different habitat variables and plant abundance for each site determined in two ways: as occupied area and plant number.

At RUL, all sites were found within a range of 527-704 metres above sea level (masl). The steeper sites occurred mostly at the lower altitudes, usually with a southern-eastern aspect, on feldspar, granite or schist, with light clay. Sites at higher altitudes tended to have a northern or western aspect, and were situated mainly on quartz with loam or silt loam. By contrast, altitude varied considerably among the eight populations (18-617 masl), with sites at higher altitudes overall steeper with an eastern-southern-southwestern aspect, an overrepresentation of the substrates feldspar and pegmatite, and silt loam. Sites at lower altitudes instead tended to be level or to have a northern aspect, and to have granite or quartz, and sand or loamy sand. Associations between the habitat parameters and the plant abundance parameters are consistent with the statistical analyses described below.

At RUL, the most common aspect group was $\mathrm{S}+\mathrm{SE}+\mathrm{E}$ (23 sites), while the other aspect groups occurred in only three to six sites each (Appendix 1, Table 2-A1). Level sites had the highest number of plants followed by SW-facing sites. Although not associated according to ANOVA (Table 3), aspect had a significant effect on plant number
TABLE 3: Importance of three habitat parameters (aspect, soil texture and substrate) for plant number and plant density determined with analysis of variance and Tukey pairwise comparisons, for 51 sites at Rössing Uranium Limited and for 43 sites at the other eight populations.

\begin{tabular}{llll}
\hline Parameter & df & $\boldsymbol{F}$ & $\boldsymbol{p}$ \\
\hline RUL & & & \\
Aspect (Plant number) & $4 / 33$ & 1.41 & 0.251 \\
Aspect (Plant density) & $4 / 29$ & 3.34 & $0.022^{*}$ \\
Soil texture (Plant number) & $3 / 47$ & 0.99 & 0.407 \\
Soil texture (Plant density) & $3 / 39$ & 1.35 & 0.272 \\
Substrate (Plant number) & $3 / 45$ & 0.49 & 0.691 \\
Substrate (Plant density) & $3 / 38$ & 0.30 & 0.827 \\
Other eight populations & & & \\
Aspect (Plant number) & $4 / 28$ & 3.64 & $0.016^{*}$ \\
Aspect (Plant density) & $4 / 26$ & 3.12 & $0.032^{*}$ \\
Soil texture (Plant number) & $2 / 40$ & 4.00 & $0.026^{*}$ \\
Soil texture (Plant density) & $2 / 37$ & 2.34 & 0.111 \\
Substrate (Plant number) & $4 / 36$ & 1.52 & 0.218 \\
Substrate (Plant density) & $4 / 33$ & 4.16 & $0.008^{* *}$ \\
\hline
\end{tabular}

For an extended version, see Appendix 1, Table 2-A1.

$*, 0.05>p>0.01 ; * *, 0.01>p>0.001$.

RUL, Rössing Uranium Limited; df, degrees of freedom.

according to GLM (Table 4). Aspect interacted with slope, due mainly to an overrepresentation of sites with an S+SE+E aspect on steeper slopes, while the flatter sites instead had more variable aspects. In the eight populations data set, the most common aspect was W (eight sites) followed by $\mathrm{SW}$ and $\mathrm{S}+\mathrm{SE}+\mathrm{E}$ (seven sites each) and $\mathrm{NE}+\mathrm{N}+\mathrm{NW}$ (six sites). According to ANOVA (Table 3), aspect had a significant impact $(F=3.64, p=0.016)$ with the highest 
TABLE 4: Factors and co-variables selected by a general linear mixed model to explain variation in plant density and total plant number for 29 sites at Rössing Uranium Limited.

\begin{tabular}{lccccc}
\hline Source of variation & $\begin{array}{c}\text { Sum of } \\
\text { squares }\end{array}$ & $\begin{array}{c}\text { Mean } \\
\text { squares }\end{array}$ & df & $\boldsymbol{F}$-value & $\operatorname{Pr}(>\boldsymbol{F})$ \\
\hline Plant density & & & & & \\
Aspect & 0.0499 & 0.0125 & $4 / 15$ & 00.29 & 0.8807 \\
Soil type & 0.0457 & 0.0152 & $3 / 15$ & 00.35 & 0.7880 \\
Substrate & 0.0083 & 0.0028 & $3 / 15$ & 00.06 & 0.9780 \\
Soil type: Substrate & 0.2233 & 0.0745 & $3 / 15$ & 01.72 & 0.2051 \\
Total plant number & & & & & \\
Altitude & 119 & 119 & $1 / 8$ & 00.15 & 0.7072 \\
Slope & 548 & 548 & $1 / 8$ & 00.70 & 0.4277 \\
Aspect & 35502 & 8876 & $4 / 8$ & 11.30 & $0.0023^{* *}$ \\
Soil type & 1029 & 343 & $3 / 8$ & 00.44 & 0.7327 \\
Substrate & 2050 & 683 & $3 / 8$ & 00.87 & 0.4956 \\
Altitude: Slope & 610 & 610 & $1 / 8$ & 00.78 & 0.4037 \\
Altitude: Aspect & 1428 & 476 & $3 / 8$ & 00.61 & 0.6294 \\
Slope: Aspect & 26143 & 8714 & $3 / 8$ & 11.10 & $0.0032^{* *}$ \\
Altitude: Slope: Aspect & 1606 & 1606 & $1 / 8$ & 02.05 & 0.1906 \\
\hline
\end{tabular}

$\mathrm{df}$, degrees of freedom.

$* *, 0.01>p>0.001$.

TABLE 5: Factors and co-variables selected by a general linear mixed model to explain variation in plant density and total plant number for 26 sites at the other eight populations.

\begin{tabular}{|c|c|c|c|c|c|}
\hline Source of variation & $\begin{array}{l}\text { Sum of } \\
\text { squares }\end{array}$ & $\begin{array}{c}\text { Mean } \\
\text { squares }\end{array}$ & df & $F$-value & $\operatorname{Pr}(>F)$ \\
\hline \multicolumn{6}{|l|}{ Plant density } \\
\hline Altitude & 0.0000 & 0.0000 & $1 / 0.00$ & 34.30 & 0.9999 \\
\hline Coastal distance & 0.0005 & 0.0005 & $1 / 0.00$ & 745.89 & 1.0000 \\
\hline Soil type & 0.0092 & 0.0046 & $2 / 2.00$ & 7569.77 & $0.0001 * *$ \\
\hline Substrate & 0.0120 & 0.0030 & $4 / 2.00$ & 4933.73 & $0.0002^{* *}$ \\
\hline Aspect & 0.0052 & 0.0013 & $4 / 2.00$ & 2143.36 & $0.0005^{* *}$ \\
\hline Slope & 0.0082 & 0.0082 & $1 / 0.00$ & 13502.79 & 1.0000 \\
\hline Soil type: Substrate & 0.0022 & 0.0011 & $2 / 2.00$ & 1836.04 & $0.0005^{* *}$ \\
\hline Soil type: Aspect & 0.0012 & 0.0004 & $3 / 2.00$ & 663.83 & $0.0015^{*}$ \\
\hline Substrate: Aspect & 0.0029 & 0.0010 & $3 / 2.00$ & 1592.39 & $0.0006^{* *}$ \\
\hline Soil type: Slope & 0.0048 & 0.0048 & $1 / 0.00$ & 7851.67 & 1.0000 \\
\hline Substrate: Slope & 0.0027 & 0.0027 & $1 / 0.00$ & 4367.92 & 1.0000 \\
\hline Aspect: Slope & 0.0026 & 0.0026 & $1 / 0.00$ & 4259.93 & 1.0000 \\
\hline \multicolumn{6}{|l|}{ Total plant number } \\
\hline Altitude & 373 & 373.5 & $1 / 0.70$ & 0.1669 & 0.7738 \\
\hline Coastal distance & 140 & 139.8 & $1 / 0.64$ & 0.0625 & 0.8593 \\
\hline Soil type & 25166 & 12582.9 & $2 / 3.47$ & 5.6234 & 0.0815 \\
\hline Substrate & 77027 & 19256.7 & $4 / 2.00$ & 8.6059 & 0.1068 \\
\hline Aspect & 5597 & 1399.3 & $4 / 2.00$ & 0.6254 & 0.6912 \\
\hline Slope & 18965 & 18965.1 & $1 / 47.15$ & 8.4756 & $0.0055^{*}$ \\
\hline Soil type: Substrate & 8218 & 4108.8 & $2 / 4.89$ & 1.8362 & 0.2541 \\
\hline Soil type: Aspect & 13534 & 4511.2 & $3 / 2.00$ & 2.0161 & 0.3485 \\
\hline Substrate: Aspect & 24999 & 8333.1 & $3 / 2.00$ & 3.7241 & 0.2189 \\
\hline Soil type: Slope & 21597 & 21596.9 & $1 / 1979.22$ & 9.6518 & $0.0020 *$ \\
\hline Substrate: Slope & 3029 & 3028.9 & $1 / 7.67$ & 1.3536 & 0.2796 \\
\hline Aspect: Slope & 47 & 46.5 & $1 / 5.76$ & 0.0208 & 0.8903 \\
\hline
\end{tabular}

$\mathrm{df}$, degrees of freedom.

$*, 0.01>p>0.001 ; * *, p<0.001$

number of plants in sites on SW-facing slopes, whereas GLM did not detect any association (Table 5).

Soil texture differed considerably between the two data sets, with only loamy sand (27 sites), silt loam (nine sites) and sand (seven sites) recorded in the eight populations, whereas clay loam, light clay, loam and silt loam were almost equally common (11-15 sites) at RUL (Appendix 1, Table 2-A1).
Soil texture did not affect plant number at RUL and there was significant impact in the eight populations $(F=4.00, p=0.026$; Table 3) only in ANOVA, with silt loam being the most beneficial.

The most common substrate at RUL was quartz + other (28 sites) followed by feldspar + other (13 sites) and granite + other (six sites), while quartz + other (17 sites), granite + other (15 sites) and pegmatite + other (four sites) were most common in the eight populations data set (Appendix 1, Table 2-A1). Substrate was not significant for plant number in either data set.

When instead plant density was used as the dependent variable in ANOVA, aspect had a significant impact both at RUL $(F=3.34, p=0.022)$ and in the eight populations $(F=3.12, p=0.032)$, with the highest densities on slopes facing SW or S+SE+E (Table 3). General linear mixed model did not detect any impact of aspect at RUL but a strong impact in the eight populations in spite of interactions with both soil texture and substrate (Table 5). Soil texture did not affect plant density in either data set according to ANOVA, while a significant association was found in the eight populations with GLM. Substrate had a significant impact for the eight populations with both ANOVA $(F=4.16$, $p=0.008$ ) and GLM (Table 5) with the highest density on pegmatite + other.

Spearman rank correlation coefficients and GLM were used to detect associations between the two quantitative habitat parameters altitude and slope, on the one hand, and plant number and plant density, on the other hand (Tables 2, 4 and 5). Altitude was not associated with either plant number or plant density. Slope was positively correlated with density in RUL $(r=0.411, p=0.012)$ and in the eight populations $(r=0.504, p=0.002)$ as well as with plant number in the eight populations ( $r=0.445, p=0.006)$. The latter was confirmed with GLM, while no association was found with plant density. In addition, impact of the distance between the site and the sea coast was investigated for the eight populations data set, and showed a negative correlation with plant density $(r=-0.308, p=0.047)$ but none with number of plants. A corresponding effect could not be shown with GLM, possibly because of the heavily reduced number (26 instead of 43) of sites included in this analysis.

The $\mathrm{pH}$ ranged between 7.7 and 9.6 in all the 30 soil samples, indicating that L. ruschiorum grows in neutral to slightly alkaline soils. The mean for RUL was 9.0, while the eight populations had a mean of 8.6. There was no correlation when $\mathrm{pH}$ was compared with plant number or plant density, but these results need to be treated with caution as only one soil sample had been taken for each site.

\section{Genetic differentiation}

A total of 52 individuals from seven populations were analysed with four primer pairs yielding 102 polymorphic 
TABLE 6: Amplified fragment length polymorphism (AFLP)-based estimates of genetic variation, within each of the seven sampled Lithops ruschiorum populations, estimated as percentage of polymorphic loci and mean expected heterozygosity $\left(H_{E}\right)$.

\begin{tabular}{lccc}
\hline Population & Number of plants & PPL & $\boldsymbol{H}_{\boldsymbol{E}}$ \\
\hline Rössing Uranium Mine (RUL) & 6 & 60.78 & 0.221 \\
Khumib River & 7 & 75.49 & 0.279 \\
Ugab River & 6 & 53.92 & 0.199 \\
Feldspar Ridge & 7 & 68.63 & 0.253 \\
Rössing Mountain & 8 & 73.53 & 0.260 \\
Henties Bay-Uis Road & 9 & 64.71 & 0.216 \\
Henties Bay-Usakos Road & 9 & 64.71 & 0.244 \\
\hline
\end{tabular}

PPL, percentage of polymorphic loci; RUL, Rössing Uranium Limited.

TABLE 7: Distribution of molecular variance among and within seven populations and six populations (without Khumib River) of $L$. ruschiorum, based on AFLP data with all results highly significant according to permutation tests $\left(p_{\text {random } \geq \text { data }}<0.001\right)$.

\begin{tabular}{lcccc}
\hline Source of variation & df & $\begin{array}{c}\text { Sum of } \\
\text { squares }\end{array}$ & $\begin{array}{c}\text { Estimated } \\
\text { variance }\end{array}$ & $\begin{array}{c}\text { Percentage of } \\
\text { variance }\end{array}$ \\
\hline Seven populations & \multicolumn{5}{l}{} & & \\
Among populations & 6 & 120.2 & 0.80 & 5 \\
Within populations & 45 & 635.6 & 14.12 & 95 \\
Six populations (without Khumib River) & & & \\
Among populations & 5 & 86.0 & 0.46 & 3 \\
Within populations & 39 & 536.1 & 13.74 & 97 \\
\hline df, degrees of freedom. & & & &
\end{tabular}

$\mathrm{df}$, degrees of freedom.

AFLP bands. Mean percentage of polymorphic loci was 65.97 and mean expected heterozygosity was 0.239 (Table 6). As expected, the two parameters co-varied, with Khumib River having the highest values followed by Rössing Mountain, whereas Ugab River had the lowest. An AMOVA showed that $95 \%$ of the variability resided within populations and $5 \%$ between populations (Table 7). Variation between populations declined to less than 3\% when repeating the analysis without the Khumib River population which is situated approximately $300 \mathrm{~km}$ from the remainder.

The Mantel test showed a correlation between geographic and genetic distances $(r=0.4179 ; p=0.001)$ when the analysis was performed on all seven populations. There was, however, no correlation $(r=0.0054, p=0.421)$ when the test was repeated without the Khumib River population.

The PCoA is a multivariate test that reveals amount of similarity among samples without presuming any group structure. The first three dimensions explained a total of $30.3 \%$ of the variance when all samples were analysed together, and showed that the Khumib River samples are widely dispersed and that many occur as outliers in the right hand and lower parts of the plots (Figures 5a and 5b). Repeating the analysis without the Khumib River samples resulted in $32.6 \%$ explained variance on the first three dimensions, and samples from all populations were intermingled without any group structure (Figure $5 \mathrm{c}$ and $5 \mathrm{~d}$ ).

\section{Discussion}

In the largest and most detailed field inventory ever published on a single Lithops species, we were able to locate nine previously recorded populations of L. ruschiorum, and estimate occupied area as well as plant number in one to several (up to 51) sites in each population. Although additional populations exist, we have probably targeted most of the larger populations of this species. We have also collected carefully quantified data in the field for five habitat variables (altitude, aspect, slope, soil texture and substrate) for each of the 94 sites, and can thus provide information on where one can expect the largest populations, evaluated as occupied area and plant number. The co-occurrence of the habitat variables and plant abundance are illustrated by statistical analyses, and the relationships determined in our study should be very valuable as a basis for further investigations on factors that impact the distribution of Lithops in the field. Molecular analysis was applied on a population level for the first time in Lithops, and revealed expected levels of within-population variation, whereas differentiation between populations was very low, and mainly because of the divergence of the geographically most distant population.

\section{Population number and population size}

The main reasons that only nine out of the 21 recorded populations were located are probably: (1) locality descriptions on herbarium specimens and in publications lack sufficient detail or are deliberately vague so as to prevent illegal collecting, and (2) the cryptic nature of the plants: in the absence of rain for a prolonged period of time, plants shrink and become concealed by their substrate. Despite spending hours looking for the population near Cape Cross, for example, we were unable to find it although it was subsequently located (Jainta 2017), and despite GPS coordinates being available another population in the central Namib could not be found. Together, the nine located populations are, however, spread over a large geographic area and should be able to provide valuable information about factors determining plant abundance in this species.

Because of the clumped distribution of plants within a population, previous attempts to apply plant density estimation methods in L. pseudotruncatella resulted in large over- or under-estimations except when using the time-consuming adaptive cluster sampling and belt transect methods (Loots \& Nybom 2017). As L. ruschiorum plants usually appear in clumped patches, efforts were made to instead obtain absolute plant counts in the present study. A number of sites were defined within each population, and plant number as well as habitat parameters were recorded. The count was probably relatively accurate for View Point, which is a small and very isolated population. In many of the other populations, our plant counts most likely grossly underestimated true plant number. Especially the Khumib River population is most likely larger than implied in this study; Google Earth images show that similar habitat extends over several square kilometres and therefore may contain many more plants. The second largest count was obtained within RUL license area where the species grows, at varying densities, on approximately $52 \mathrm{~km}^{2}$. 


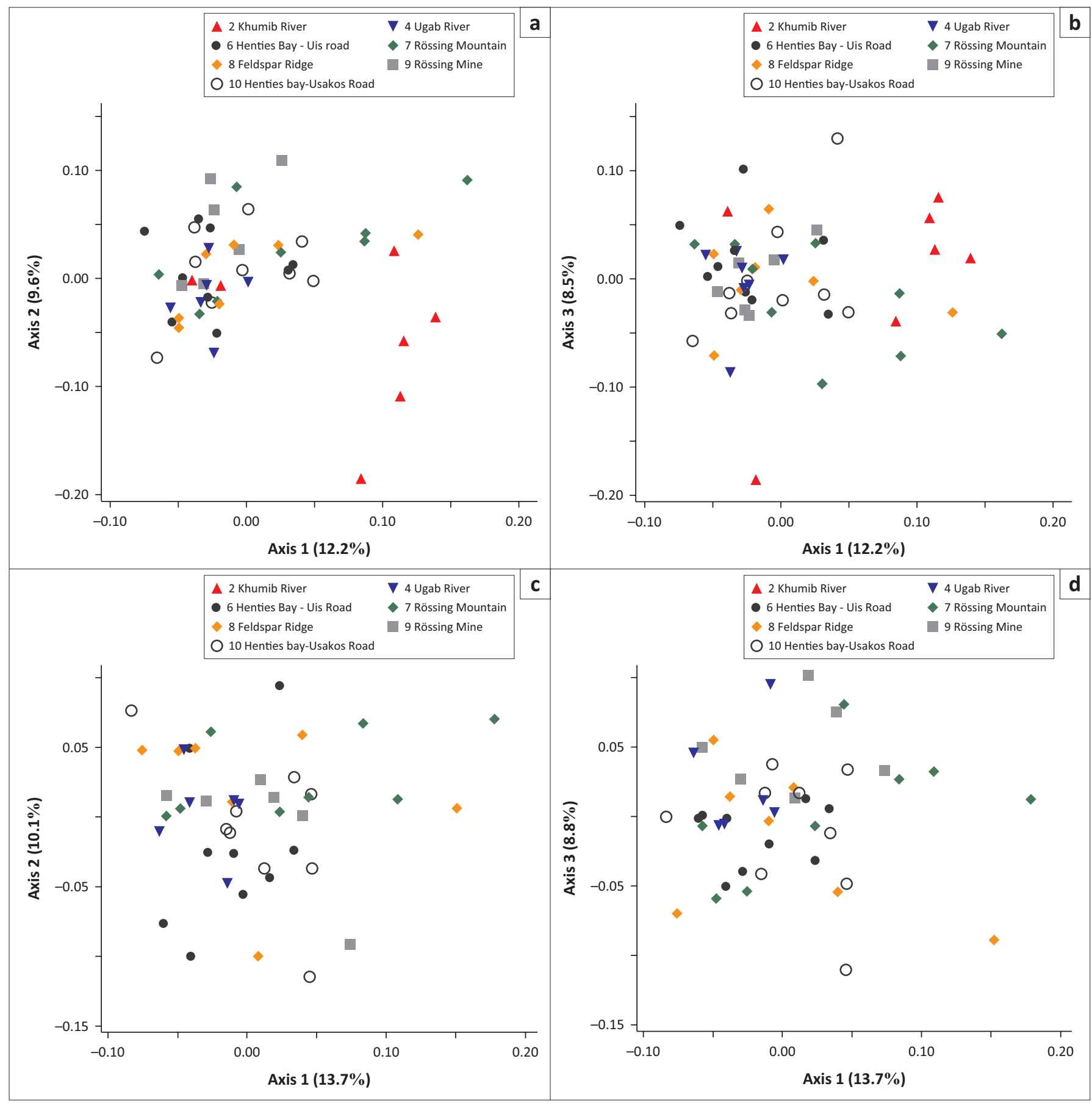

FIGURE 5: Principal coordinate analysis of amplified fragment length polymorphism data for 52 plants derived from seven populations of Lithops ruschiorum. (a) and (c) show dimensions 1 and 2, while (b) and (d) show dimensions 1 and 3. (a) and (b) include all populations, whereas (c) and (d) exclude the somewhat deviating population Khumib River.

\section{Plant number, occupied area and plant density}

A clumped distribution has been described for many species in the family Aizoaceae (Burke \& Mannheimer 2003; Ihlenfeldt 1983), and was thoroughly investigated in L. pseudotruncatella (Loots \& Nybom 2017). Designation of several separately analysed sites within populations in the present study allowed detailed description of the occurrence of Lithops plants and their habitat preferences. Occupied area as well as plant number varied strongly among sites in both data sets, but, on average, sites were almost four times larger in the eight populations and contained almost four times as many plants compared to sites in RUL. Calculated across the individual sites within each data set, mean density was more than four times higher in the eight populations. Occupied area was positively correlated with plant number, and negatively correlated with plant density in both data sets. Plant number and density were positively correlated in the eight populations, where some large sites were densely populated. By contrast, large sites at RUL usually contained relatively few plants per square metre.

\section{Impact of habitat characteristics}

Fog has a crucial impact on all vegetation in the Namib desert. The high fog zone extends up to $60 \mathrm{~km}$ inland from 
the Atlantic Ocean and produces fog-derived precipitation 60-120 days per year (Mendelsohn et al. 2002; Robertson et al. 2012). Here, fog may produce five times as much precipitation as rain, and fog is also more predictable, thus affecting the distribution of many plant species in the Namib desert (Hachfeld \& Jürgens 2000; Lancaster et al. 1984; Olivier 1995; Seely \& Henschel 1998; Seely \& Pallet 2008). In a study on present and projected impacts on the distribution of the genus Lithops in Namibia, Guo et al. (2017) quantified the effects of several environmental variables scored from climatic and topographic maps. The percentual contribution was highest for terrain morphology (roughly equivalent to slope in our study) with $24 \%$, followed by soil texture with $21 \%$, number of fog days (roughly equivalent to coastal distance in our study) with $20 \%$, geology (rock substrate in our study) with $18 \%$ and altitude with $6 \%$. In addition, relative humidity (not measured in our study) accounted for $11 \%$. A close dependency on specific habitats, especially for taxa inhabiting the Namib desert region, has also been described for another dwarf succulent, namely Conophytum N.E.Br. (Young \& Desmet 2016). Climate projections for the 2070s suggest that Lithops is likely to suffer from a severe range contraction caused mainly by a reduction in the number of fog days (Guo et al. 2017).

Although it takes rainfall events to trigger germination and initial establishment of Lithops plants, regular fog precipitation may be more important for plant survival and growth, especially in species like L. ruschiorum. A combination of the amount of fog precipitation and occurrence of an otherwise suitable habitat may thus have great impact on plant abundance in this species. Eight of our studied populations are located within the high fog zone, where lower air temperatures and higher humidity allow them to benefit from the various types of fog (Seely \& Henschel 1998). By contrast, the RUL population is situated approximately $60 \mathrm{~km}$ inland, in the outskirts of the high fog zone. Here, higher air temperatures and lower air humidity may overcome the effect of fog precipitation (Hachfeld \& Jürgens 2000) and plants growing here are probably more dependent on rain (Hachfeld 2000).

Estimation of plant abundance is not straightforward in species with a patchy or heavily clumped distribution. Plant number and occupied area provide different estimates of the size of a plant site, but plant density was more closely associated with most of the habitat variables and therefore appears to be superior for determination of habitat preferences. It should also be stressed that the associations reported in this study are tentative only, as a larger set of more balanced data is needed for exploration of the true magnitude of impact from each habitat parameter.

Altitude most likely affects the ability of the sites to retain fog precipitation, but the range was very small at RUL (527-704 m) and no associations were found. The larger range recorded in the eight populations data set $(18-617 \mathrm{~m})$ possibly helped to detect a positive association with plant number as indicated in the PCA (Figure 4) although no significant impact could be established with correlation analysis or GLM.

Slope ranged from $0^{\circ}$ to $40^{\circ}$ at RUL and between $0^{\circ}$ and $25^{\circ}$ in the eight populations. In the latter data set, positive correlations were found between slope, on the one hand, and plant number and density, on the other hand. These associations are most likely because of an increased interception of fog precipitation at the steeper slopes found on inselbergs and rocky ridges. Interestingly, some of the largest and densest populations were found on overall steeper terrain, such as Khumib River, Hoanib River, Rössing Mountain and Feldspar Ridge. As RUL is located further inland, steeper slopes will not have the same beneficial effect. The weaker but still significant positive correlation between plant density and slope at RUL would instead be because the hilly terrain harbours overall smaller sites with high plant densities. By contrast, the level terrain at RUL consists of gravel plains interrupted by dry sandy water courses and holds fewer plants albeit often on large surfaces.

Distance from the coast may have an impact on plant abundance, given that fog-derived precipitation plays an important role although surface winds, carrying fog from the ocean, as well as the often variable mountain-plain winds, should not be underestimated (Seely \& Henschel 1998). As expected, coastal distance was negatively correlated with plant density in the eight populations, but there were some exceptions: although close to the ocean, the slope on which the small View Point population grows is unable to retain much fog. By contrast, the large Khumib River population is further inland but situated on slopes in fog-trapping valleys.

Aspect had considerable influence, with plant number being the highest on SW-facing slopes in the eight populations. SW- and S-E-facing slopes also harboured sites with the highest density in both data sets. The beneficial impact of SW-facing slopes is consistent with the fog arriving with coastal winds (Seely \& Henschel 1988). In the putatively less fog-dependent RUL population, the majority of the analysed sites were, however, found on S-E-facing slopes. In Namibia, rain usually arrives with eastern winds, and the raindependent L. pseudotruncatella had its highest plant density in S-E- or S-facing plots (Loots \& Nybom 2017).

Substrate had no significant impact on plant number or density at RUL, while a positive influence was demonstrated in the eight populations with pegmatite+other doing best. Moreover, most of the L. ruschiorum sites were recorded on quartz, feldspar or granite which are light-coloured in the distribution area of this species. Two of the sites in Rössing Mountain occurred on a darker substrate, commonly found on this inselberg characterised by dark mottled and banded gneiss of the Khan formation. Here, the darker colour is perhaps outweighed by other positive factors such as the short distance from the sea and suitable elevation and aspect. 
An impact of soil texture was noted only in the eight populations where silt loam appears to be more beneficial than sandy loam or sand. Sand had a negative impact also on L. pseudotruncatella (Loots \& Nybom 2017), possibly because sand cannot provide necessary stabilisation for the small root systems of Lithops.

\section{Genetic structure}

Amplified fragment length polymorphism markers have been used to successfully investigate differentiation at population level of species in the sub-family Ruschioideae (Buys et al. 2008; Ellis, Weis \& Gaut 2006), and nine clades were defined within the genus Lithops (Kellner et al. 2011). To our knowledge, the present study is, however, the first to use DNA markers to study genetic diversity between and within populations of a single Lithops species.

Within-population diversity estimated as expected heterozygosity had a mean of 0.24 , which is similar to previously reported values and also in keeping with random amplified polymorphism DNA (RAPD)-derived estimates for short-lived perennials (0.20), with narrowrange distribution (0.28), outcrossing breeding system (0.27), water-dispersed seeds $(0.27)$ and growing in earlysuccessional vegetation (0.17; Nybom 2004). The fact that the large Khumib River population is also the most diverse (0.28) could suggest that recognition of two varieties of L. ruschiorum (both of which were found in this population) is associated with increased diversity but more sampling is required to investigate possible differentiation between these taxa.

Only 5\% of the genetic variability occurred among populations, indicating very low differentiation. Lithops is outcrossing, and probably pollinated by a variety of insects (Cole \& Cole 2005; Smith et al. 1998), suggesting that gene flow could be prominent. Still, values around 25\% - 35\% are usually found in outcrossing species sampled from populations within a restricted distribution (Nybom 2004). The low differentiation in our study may be indicative of a relatively recent fragmentation of a previously larger population. In addition, there are almost certainly populations that are still unrecorded and that contribute to gene flow among populations. According to both the PCoA and the Mantel test, the only genetically divergent population is Khumib River which is situated at least $300 \mathrm{~km}$ from the other populations.

\section{Conservation status of Lithops ruschiorum}

In the assessment for the Red Data Book (Loots 2005), the largest population of L. ruschiorum was inferred to contain no more than 1100 mature plants. The present study shows that there are at least two populations with over 2000 plants, with the largest at Khumib River in the Skeleton Coast Park. The second largest, at RUL, should also be conserved, especially considering its distance from the Skeleton Coast Park, the long-term monitoring programme for L. ruschiorum that is based there and the fact that the mine has recently changed ownership.

Number of juveniles is likely to be grossly underestimated, and recruitment probably takes place in most populations. Witkowski and Liston (1997) report that population dynamics in Haworthia koelmaniorum Oberm. \& D.S.Hardy are characterised by adult persistence because seedling establishment is most likely episodic. This may also be true for Lithops, emphasising the importance of conserving adults in their habitat.

The current status of Least Concern remains valid for L. ruschiorum, but many threats from habitat destruction prevail. Bulldozer tracks across some of the habitat at RUL have not been re-colonised since the inception of the mine 30 years ago. In other populations with off-road driving, no L. ruschiorum were recorded in the vehicle tracks but age of the tracks cannot be determined. Some sites are vulnerable to both off-road driving, for example the ones between Henties Bay and Uis, where there is no protection. Anecdotal evidence from the last ten years suggests that poaching of Lithops may be on the rise. Herbivory of Lithops plant bodies by animals (possibly springbok, hares, grasshoppers, armoured crickets, birds and rodents) often result in the death of plants, but it is not known how this affects the overall mortality rate. Prolonged dry periods can increase grazing pressure as demonstrated at RUL, which, in turn, can lead to increased desertification thus threatening dwarf succulents in arid environments.

\section{Conclusions}

Results are concordant with a strong impact of fog-based precipitation on especially plant density in populations closer to the coast, whereas rain is probably more important at RUL which is situated further inland. Within-population genetic variation was medium high but the low population differentiation implies considerable gene flow and/or recent population fragmentation and holds clues for a conservation strategy for the species.

\section{Acknowledgements}

J.-E. Englund is thanked for statistical help, M. Fatih for logistical support in Sweden and the staff of the Senckenberg BIK-F laboratory (Frankfurt am Main, Germany) for technical support in AFLP analyses. Financial support was received from Rio Tinto, RBG Kew, Rössing Uranium Limited, MAWF and Sida (Swedish International Development Cooperation Agency) as part of Nordic support to SADC Plant Genetic Resources Project. Staff of the National Botanical Research Institute assisted with field work and logistical support.

\section{Competing interests}

The authors declare that they have no financial or personal relationships that may have influenced them in writing this article. 


\section{Authors' contributions}

S.L. designed the study, performed the field work and most of the statistical evaluations, carried out most of the laboratory work and had a leading role in writing this manuscript. C.M.R. supervised the laboratory work, performed the AFLP data evaluations and contributed to this manuscript. M.S. assisted with the laboratory work. J.S. performed the AFLP band scoring. V.H. conducted some of the statistical analyses. L.G.-G. contributed to this manuscript. H.E.N. supervised the study and assisted in writing this manuscript.

\section{Funding}

Rio Tinto, Rössing Uranium Limited, MAWF and SADC Plant Genetic Resources Centre (SPGRC) and Sida (Swedish International Development Cooperation Agency) as part of the Nordic support to the SADC Plant Genetic Resources Project. Senckenberg BIK-F laboratory (Frankfurt am Main, Germany) provided technical support for AFLP analyses.

\section{Data availability statement}

Data created during this study belong to the Government of Namibia and the authors. Data sharing is possible with the application of information request forms, available on the website of the National Botanical Research Institute of Namibia (http://www.nbri.org/) or by contacting the authors.

\section{Disclaimer}

The views expressed in the submitted article are our own, and do not represent anyone else.

\section{References}

Banks, T.W. \& Benham, J.J., 2008, Genographer version 2.1.4, Montana State University, Bozeman, MT.

Bates, D., Maechler, M., Bolker, B. \& Walker, S., 2015, 'Fitting linear mixed-effects models using Ime4', Journal of Statistical Software 67(1), 1-48. https://doi. org/10.18637/jss.v067.i01

Burke, A., 2005, Rössing's Biodiversity strategy: Biotope mapping, reconstruction of the pre-mining situation and assessment of biodiversity value, Phase 2 report, Enviroscience, Windhoek.

Burke, A. \& Mannheimer, C.A., 2003, 'Towards a density measure for assessments of arid plant populations - examples from the southern Namib Desert', African Journal of Ecology 41(3), 254-256. https://doi.org/10.1046/j.1365-2028.2003.00447.x

Buys, M.H., Janse Van Rensburg, L.-L., Mienie, C.M.S., Barker, N., Burgoyne, P.M., Mills, L. et al., 2008, 'Applying AFLPs in Aizoaceae: The Delosperma herbeum complex as a case study', Biochemical Systematics and Ecology 36(2), 92-100. https://doi. org/10.1016/j.bse.2007.08.003

Cole, D.T., 1988a, Lithops flowering stones, Acorn Books CC \& Russel Friedman Book CC, Johannesburg.

Cole, D.T., 1988b, Lithops locality data, (Numerical index C001-C392, and alphabetical species index), 3rd edn., Author, Johannesburg.

Cole, D.T. 2006, Lithops - two new taxa, pp. 57-63, Cactus \& Co., Tradate

Cole, D.T. \& Cole, N.A., 2001, Ruschioideae: Lithops, in H.E.K. Hartmann (ed.), Illustrated Handbook of succulent plants: Aizoaceae, F-Z, pp. 114-135, Springer, Berlin.

Cole, D.T. \& Cole, N.A., 2005, Lithops flowering stones, Cactus \& Co., Tradate

Ellis, A.G., Weis, A.E. \& Gaut, B.S., 2006, "Evolutionary radiation of "stone plants" in the genus Argyroderma (Aizoaceae): Unravelling the effects of landscape, habitat, and flowering time', Evolution 60(1), 39-55. https://doi.org/10.1111/j.0014-3820.2006. tb01080.x

Guo, D., Young, A.J., Desmet, P.G. \& Midgley, G.F., 2017, 'Climate change impacts on dwarf succulents in Namibia as a result of changes in fog and relative humidity', Journal of Water Resource and Hydraulic Engineering 6(3), 57-63. https://doi. org/10.5963/JWRHE0603004
Hachfeld, B., 2000, 'Rain, fog and species richness in the central Namib desert in the exceptional rainy season of 1999/2000', Dinteria 26, 113-146.

Hachfeld, B. \& Jürgens, N., 2000, 'Climate patterns and their impact on the vegetation in a fog driven desert: The central Namib desert in Namibia', Phytocoenologia 30(3-4), 567-589. https://doi.org/10.1127/phyto/30/2000/567

Ihlenfeldt, H.D., 1983, 'Dispersal of Mesembryanthemaceae in arid habitats', Sonderbände Des Naturwissenschaftlichen Vereins Hamburg 7, 381-390.

Irish, J., 1994, 'The biomes of Namibia, as determined by objective categorisation', Navorsinge van die Nationale Museum Bloemfontein 10(13), 550-591.

IUCN, 2001, IUCN red list categories and criteria, Version 3.1, IUCN Species Survival Commission, IUCN, Gland and Cambridge.

Jainta, H., 2017, Wild Lithops, Klaus Hess publisher, Göttingen and Windhoek.

Kellner, A., Ritz, C.M., Schlittenhardt, P. \& Hellwig, F.H., 2011, 'Genetic differentiation in the genus Lithops $L$. (Ruschioideae, Aizoaceae) reveals a high level of convergent evolution and reflects geographic distribution', Plant Biology 13(2), 368-380. https://doi.org/10.1111/j.1438-8677.2010.00354.x

Klaassen, E.S. \& Kwembeya, E.G., (Eds.), 2013, A checklist of Namibian indigenous and naturalised plants, Occasional Contributions No. 5, National Botanical Research Institute, Windhoek.

Kuznetsova, A., Brockhoff, P.B. \& Christensen, R.H.B., 2017, 'ImerTest Package: Tests in linear mixed effects models', Journal of Statistical Software 82(13), 1-26. https:// doi.org/10.18637/jss.v082.i13

Lancaster, J., Lancaster, N. \& Seely, M.K., 1984, 'Climate of the central Namib desert', Madoqua 14(1), 5-61.

Loots, S., 2005, 'Red data book of Namibian plants', Southern African Botanical Diversity Report No. 38. SABONET, Pretoria and Windhoek, $124 \mathrm{pp}$.

Loots, S., 2011, National conservation assessment and management of two Namibian succulents, with specific reference to the Rössing Uranium Mine, Report on a partnership project between the National Botanical Research Institute of Namibia, Rössing Uranium Limited, The Rio Tinto Group and the Royal Botanic Gardens, Kew, Unpublished.

Loots, S. \& Nybom, H., 2017, 'Towards better risk assessment for conservation of flowering stones: Plant density, spatial pattern and habitat preference of Lithops pseudotruncatella in Namibia', South-African Journal of Botany 109, 112-115. https://doi.org/10.1016/j.sajb.2016.12.023

Mannheimer, C.A. \& Loots, S., 2012, 'A simple aid to assessing cryptic succulents in the field', Dinteria 32, 78-80.

Mendelsohn, J., Jarvis, A., Roberts, C. \& Robertson, A., 2002, Atlas of Namibia, David Phillip Publishers, Cape Town.

National Herbarium of Namibia (WIND), 2006, SPMNDB Database, Nationa Herbarium of Namibia (WIND), National Botanical Research Institute, MAWF, Windhoek.

Nei, M., 1978, 'Estimation of average heterozygosity and genetic distance from a small number of individuals', Genetics 89(3), 583-590.

Nybom, H., 2004, 'Comparison of different nuclear DNA markers for estimating intraspecific genetic diversity in plants', Molecular Ecology 13(5), 1143-1155. https://doi.org/10.1111/j.1365-294X.2004.02141.x

Olivier, J., 1995, 'Spatial distribution of fog in the Namib', Journal of Arid Environments 29(2), 129-138. https://doi.org/10.1016/S0140-1963(05)80084-9

Peakall, R. \& Smouse, P., 2012, 'GENALEX 6.5: Genetic analysis in Excel. Population genetic software for teaching and research - An update, Bioinformatics 28(19), 2537-2539. https://doi.org/10.1093/bioinformatics/bts460

R Core Team, 2018, R: A language and environment for statistical computing, $\mathrm{R}$ Foundation for Statistical Computing, Vienna, Austria, available online (2019-05-14) at https://www.R-project.org/.

Robertson, A., Jarvis, A., Mendelsohn, J. \& Swart, R., 2012, 'Chapter 2: Weather and water' in: Namibia's coast: Ocean riches and desert treasures, pp. 20-45, Directorate of Environmental Affairs, Ministry of Environment and Tourism, Namibia.

Schuelke, M., 2000, 'An economic method for the fluorescent labelling of PCR fragments', Nature Biotechnology 18(2), 233-234.

Schwantes, G., 1957, 'Flowering Stones and Mid-Day Flowers', Ernest Benn, London.

Seely, M.K. \& Henschel, J.R., 1998, 'The climatology of Namib fog', in Proceedings of the $1^{\text {st }}$ Conference on fog and fog collection, 19-24 July 1998, Vancouver.

Seely, M.K. \& Pallet, J., 2008, 'Namib Secrets of a Desert Uncovered', Venture Publications, Windhoek.

Smith, G.F., Chesselet, P., Van Jaarsveld, E.J., Hartmann, H., Hammer, S., Van Wyk, B.E. et al. 1998, 'Mesembs of the World: Illustrated Guide to a Remarkable Succulent Plant Group', Briza Publications, Pretoria.

Vos, P., Hogers, R., Bleeker, M., Reijans, M., Van De Lee, T., Hornes, M. et al., 1995 'AFLP: A new technique for DNA fingerprinting', Nucleic Acids Research 23 (21) 4407-4414.

Witkowski, E.T.F. \& Liston, R.J., 1997, 'Population structure, habitat profile and regeneration of Haworthia koelmaniorum, a vulnerable dwarf succulent, endemic to Mpumalanga, South Africa', South-African Journal of Botany 63(6), 363-370. https://doi.org/10.1016/S0254-6299(15)30787-0

Young, A.J. \& Desmet, P.G., 2016, 'The distribution of the dwarf succulent genus Conophytum N.E.Br. (Aizoaceae) in southern Africa', Bothalia 46(1), a2019. http:// doi.org/10.4102/abc.v46i1.2019 


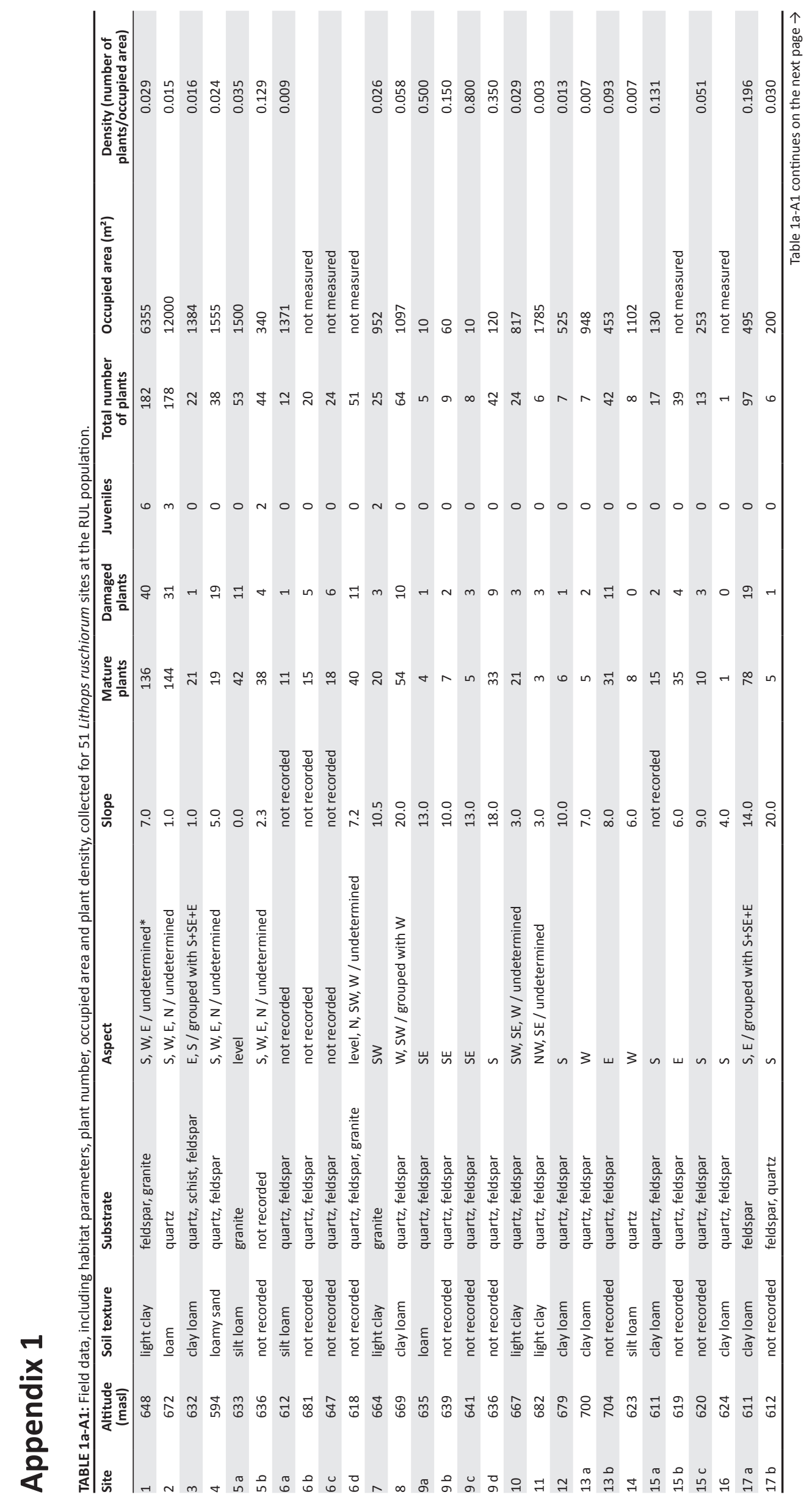




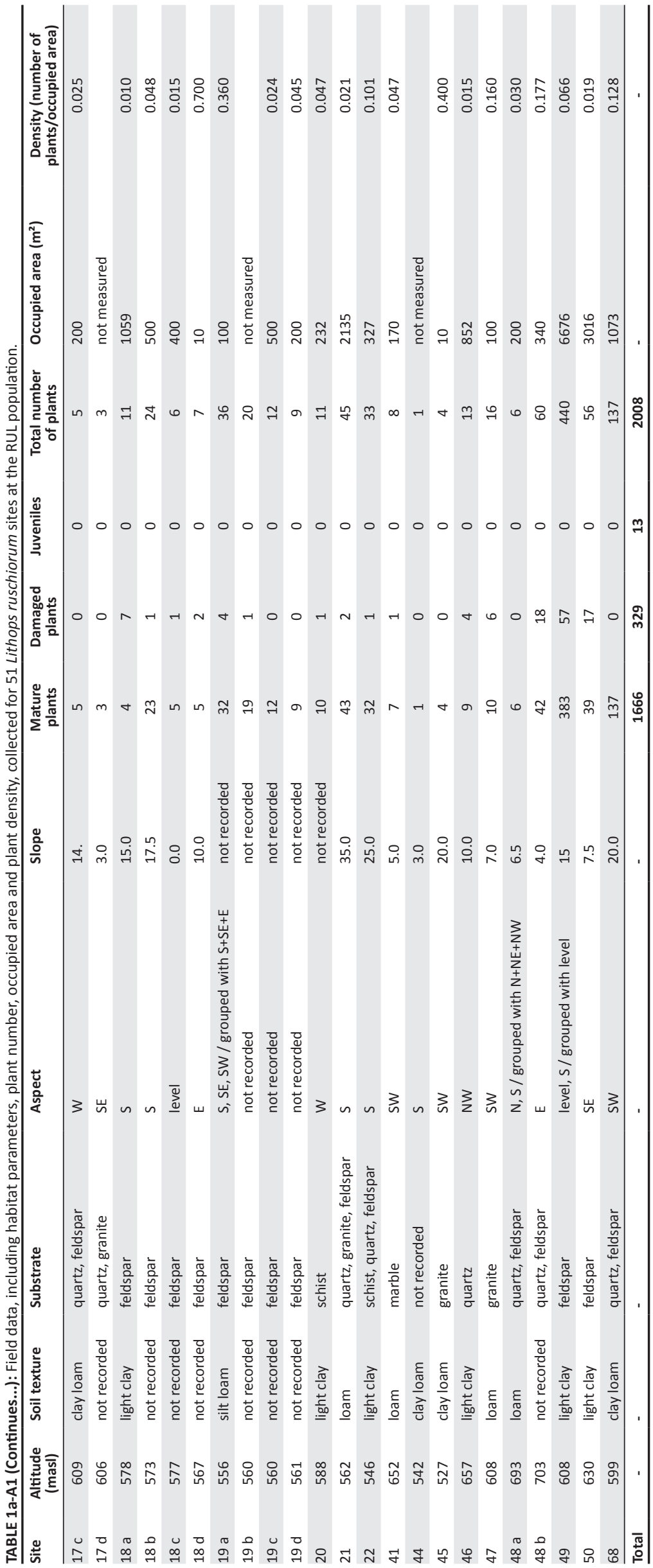




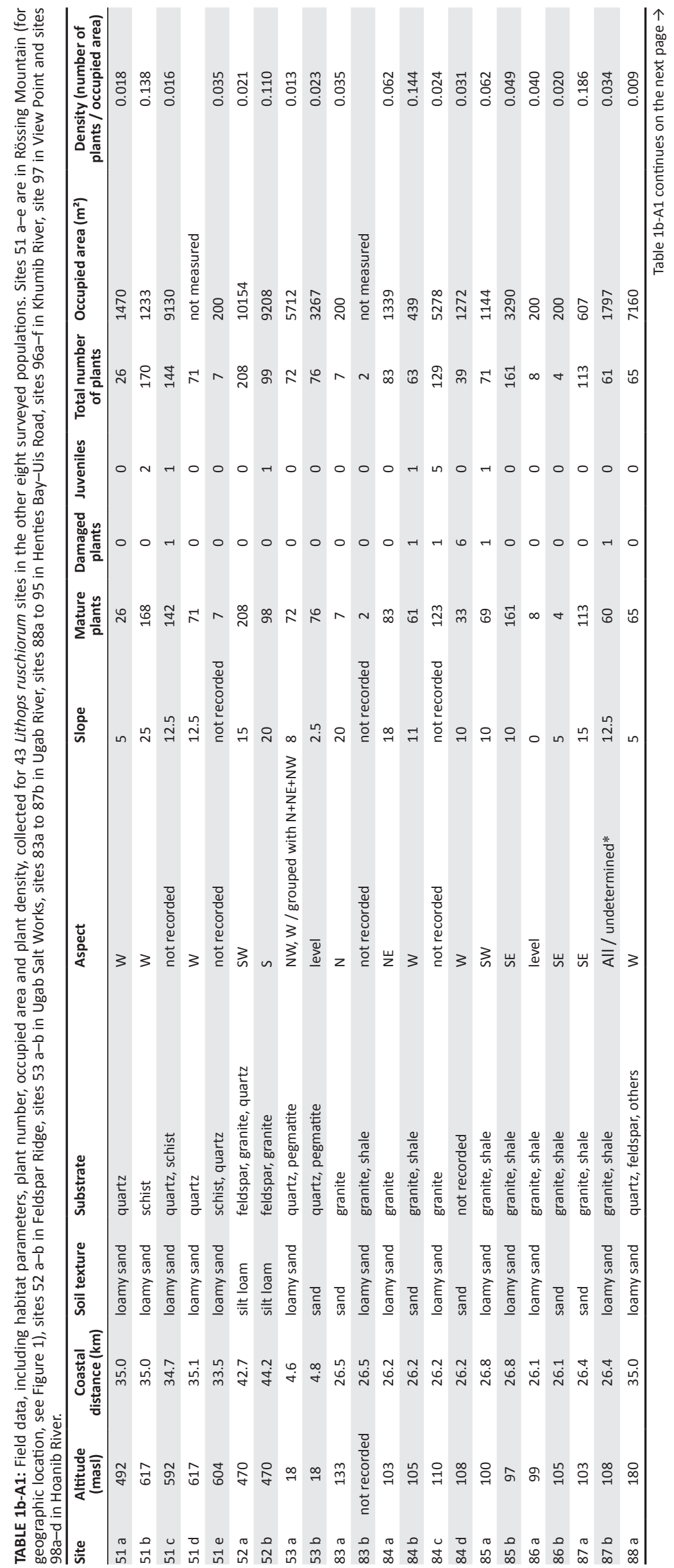




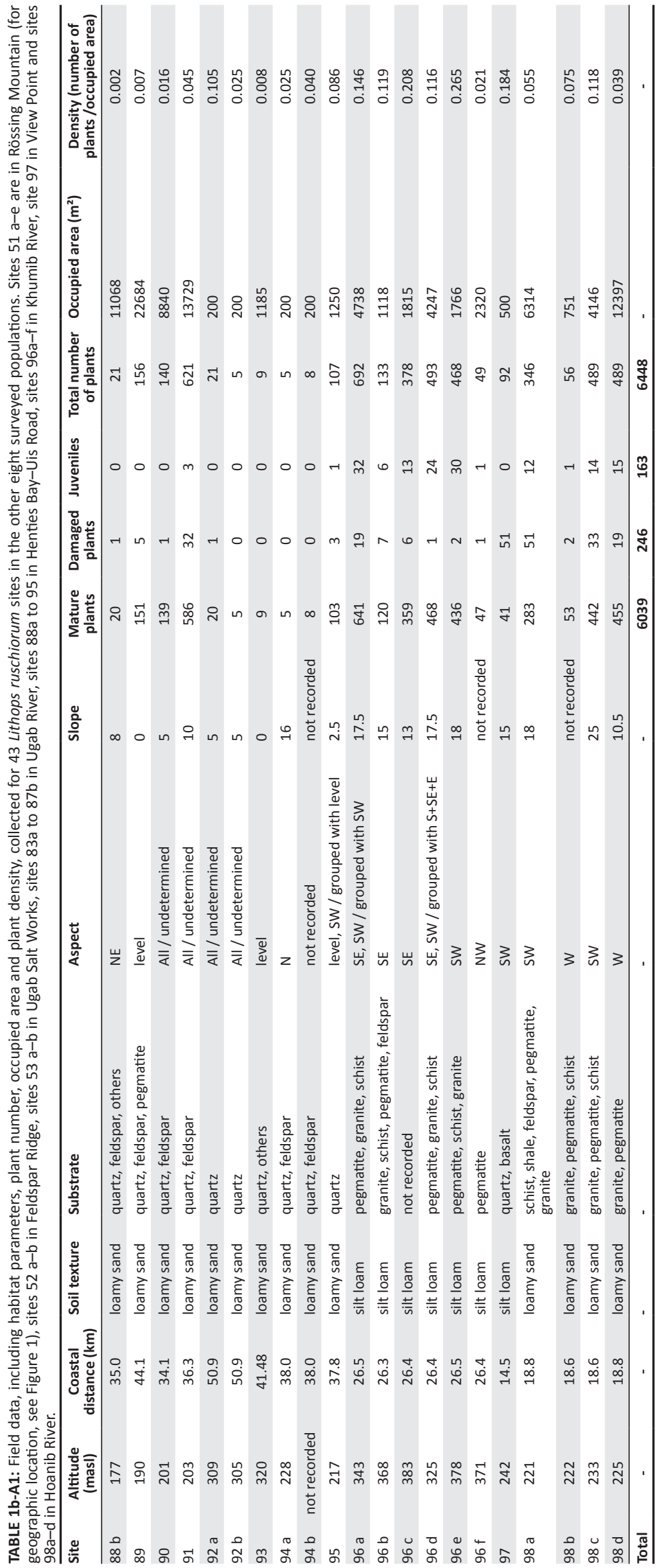


TABLE 2-A1: Details of ANOVAs performed to investigate the effect of aspect, substrate and soil texture on plant number and density at RUL and the other 8 populations, accompanied by Tukey test grouping (TTG): entries with identical letters do not differ at $P<0.05$. Mean values are based on natural logarithm transformations.

\begin{tabular}{|c|c|c|c|c|c|c|c|}
\hline Parameter & Categories & $N$ & Mean & DF & $F$ & $P$ & TTG \\
\hline \multicolumn{8}{|l|}{ RUL } \\
\hline \multirow{5}{*}{$\begin{array}{l}\text { Aspect } \\
\text { (Number) }\end{array}$} & level & 3 & 4.0 & $4 / 33$ & 1.41 & 0.251 & A \\
\hline & sW & 6 & 3.1 & & & & A \\
\hline & $\mathrm{S}+\mathrm{SE}+\mathrm{E}$ & 23 & 2.7 & & & & A \\
\hline & $\mathrm{NE}+\mathrm{N}+\mathrm{NW}$ & 3 & 2.1 & & & & A \\
\hline & W & 4 & 2.0 & & & & A \\
\hline \multirow{5}{*}{$\begin{array}{l}\text { Aspect } \\
\text { (Density) }\end{array}$} & SW & 6 & -2.4 & $4 / 29$ & 3.34 & 0.022 & A \\
\hline & $\mathrm{S}+\mathrm{SE}+\mathrm{E}$ & 19 & -2.4 & & & & A \\
\hline & level & 3 & -3.4 & & & & A \\
\hline & w & 4 & -4.1 & & & & A \\
\hline & $\mathrm{NE}+\mathrm{N}+\mathrm{NW}$ & 3 & -4.5 & & & & A \\
\hline \multirow{4}{*}{$\begin{array}{l}\text { Substrate } \\
\text { (Number) }\end{array}$} & feldspar + other & 13 & 3.3 & $3 / 45$ & 0.49 & 0.691 & A \\
\hline & granite + other & 6 & 3.2 & & & & A \\
\hline & schist + other & 2 & 3.0 & & & & A \\
\hline & quartz + other & 28 & 2.8 & & & & A \\
\hline \multirow{4}{*}{$\begin{array}{l}\text { Substrate } \\
\text { (Density) }\end{array}$} & granite + other & 6 & -2.6 & $3 / 38$ & 0.30 & 0.827 & A \\
\hline & schist + other & 2 & -2.7 & & & & A \\
\hline & feldspar + other & 12 & -3.0 & & & & A \\
\hline & quartz + other & 22 & -3.2 & & & & A \\
\hline \multirow{4}{*}{$\begin{array}{l}\text { Soil texture } \\
\text { (Number) }\end{array}$} & light clay & 14 & 3.2 & $3 / 47$ & 0.99 & 0.407 & A \\
\hline & silt loam & 11 & 3.1 & & & & A \\
\hline & loam & 11 & 3.0 & & & & A \\
\hline & clay loam & 15 & 2.4 & & & & A \\
\hline \multirow{4}{*}{$\begin{array}{l}\text { Soil texture } \\
\text { (Density) }\end{array}$} & loam & 11 & -2.3 & $3 / 39$ & 1.35 & 0.272 & A \\
\hline & clay loam & 11 & -3.0 & & & & A \\
\hline & silt loam & 7 & -3.3 & & & & A \\
\hline & light clay & 14 & -3.4 & & & & A \\
\hline \multicolumn{8}{|c|}{ Other 8 populations } \\
\hline \multirow{5}{*}{$\begin{array}{l}\text { Aspect } \\
\text { (Number) }\end{array}$} & SW & 7 & 2.4 & $4 / 28$ & 3.64 & 0.016 & A \\
\hline & $S+S E+E$ & 7 & 2.0 & & & & A \\
\hline & W & 8 & 1.9 & & & & A \\
\hline & level & 5 & 1.6 & & & & A \\
\hline & $\mathrm{NE}+\mathrm{N}+\mathrm{NW}$ & 6 & 1.4 & & & & A \\
\hline \multirow{5}{*}{$\begin{array}{l}\text { Aspect } \\
\text { (Density) }\end{array}$} & SW & 7 & -2.4 & $4 / 26$ & 3.12 & 0.032 & A \\
\hline & $\mathrm{S}+\mathrm{SE}+\mathrm{E}$ & 6 & -2.5 & & & & A \\
\hline & W & 7 & -3.1 & & & & A \\
\hline & level & 5 & -3.9 & & & & A \\
\hline & $\mathrm{NE}+\mathrm{N}+\mathrm{NW}$ & 6 & -4.1 & & & & A \\
\hline \multirow{5}{*}{$\begin{array}{l}\text { Substrate } \\
\text { (Number) }\end{array}$} & pegmatite + other & 4 & 2.5 & $4 / 36$ & 1.52 & 0.218 & A \\
\hline & feldspar + other & 2 & 2.2 & & & & A \\
\hline & schist + other & 3 & 1.9 & & & & A \\
\hline & granite + other & 15 & 1.7 & & & & A \\
\hline & quartz + other & 17 & 1.7 & & & & A \\
\hline \multirow{5}{*}{$\begin{array}{l}\text { Substrate } \\
\text { (Density) }\end{array}$} & pegmatite + other & 4 & -2.3 & $4 / 33$ & 4.16 & 0.008 & A \\
\hline & schist + other & 3 & -2.7 & & & & $A B$ \\
\hline & granite + other & 13 & -2.8 & & & & A \\
\hline & quartz + other & 16 & -3.8 & & & & B \\
\hline & feldspar + other & 2 & -4.2 & & & & $A B$ \\
\hline \multirow{3}{*}{$\begin{array}{l}\text { Soil texture } \\
\text { (Number) }\end{array}$} & silt loam & 9 & 2.3 & $2 / 40$ & 4.00 & 0.026 & A \\
\hline & loamy sand & 27 & 1.7 & & & & B \\
\hline & sand & 7 & 1.6 & & & & $A B$ \\
\hline \multirow{3}{*}{$\begin{array}{l}\text { Soil texture } \\
\text { (Density) }\end{array}$} & silt loam & 9 & -2.6 & $2 / 37$ & 2.34 & 0.111 & A \\
\hline & sand & 6 & -3.2 & & & & A \\
\hline & loamy sand & 25 & -3.5 & & & & A \\
\hline
\end{tabular}

